\title{
An Empirical Assessment of the Relationship Between Management Levels and Planning Among Small Business Practitioners
}

James W. Carland

JoAnn C. Carland

Carroll D. Aby, Jr.

College of Business

Western Carolina University

Cullowhee, North Carolina

Planning in small businesses has been the subject of considerable research. Virtually every issue of the Strategic Management Journal contains at least one article dedicated to that subject. Numerous researchers have found that planning activities improve organizational performance (i.e., [17], [22], [15], [26], [27], [28]), but there is not uniform agreement in support of this conclusion (i.e. [5], [8], [18], [3]). Neither can scholars agree as to how organizational performance should be measured [19]. Furthermore, unanimity of thought does not exist on how strategic planning takes place in a small business [24]. Rhyne [16] presents an excellent overview of the studies on planning and performance, pointing out inconsistencies and suggesting that the diversity of findings may result from omission of planning characteristics. Despite the controversy, one thing that most scholars have in common is a recognition that vast numbers of small firms do not plan at all! A number of studies have dealt with this problem (i.e. [7], [20], [4]).

According to Chandler [2], one of the most important factors in management is the structure of the organization. Chandler's work reveals that lower levels of management are more oriented toward operations and therefore less toward planning. Chandler makes it clear that planning and structure are inextricably bound. Miller and Toulouse [10] examined the impact of structure and other variables on the performance of a firm and found that delegation of authority was highly correlated with performance. Thus one might argue implicitly that the simpler the structure of a firm, the less likely it is to engage in planning activities.

This study will examine the interaction of organizational structure and the presence of planning activities without regard to planning type, intensity, or impact. Considering that a more simplistic management structure results in a greater level of involvement of owner/managers in operational issues, the

Journal of Business Strategies, Volume 5, Number 1 (Spring 1988) 
study will examine whether the theoretical freedom from operations inherent in organizations with more complex management structures results in greater planning activities.

Planning activities will refer to whether an owner/manager has engaged in the development of a formal, written plan for the development and growth of the firm; engaged in the development of an informal, unwritten plan; or failed to develop either a written or unwritten plan.

Definitional issues with regard to small businesses will be discussed and a taxonomy of small businesses espoused. The results of an empirical test of the taxonomy with respect to the presence of written or unwritten plans will conclude the paper.

\section{Small Business Definitions}

A frequently cited definition of small business is contained in the Small Business Administration guidelines for loan assistance. The SBA requires that a firm be independently owned and operated. Further, to be classified as a small business the firm must not be dominant in its field. To activate this definition, the SBA publishes a booklet with arbitrary cut off points in sales or employees, but will examine any firm which fails to fulfill published guidelines to ascertain whether it qualifies as a small business.

McGuire [9] reeognized the need for classification criteria and suggested that businesses which encompass a single "profit center" be classified "small." Firms comprised of more than one profit center would connote a large business. McGuire's "profit center" orresponds to the "strategic business unit" described by Glueck [6]. Glueck's [6] SBU was an entity or operating division serving a distinct product/market segment and having authority to make its own strategic decisions. An SBU can have multiple outlets or locations so long as those sites serve the same product/market segment.

Schollhammer and Kuriloff [23] considered a business small if the proprietor could know each company member by name. Although their meaning is clear, such a definition could hardly be utilized to structure research. Many writers circumvent the issue entirely by neglecting to define a small business. This latter practice is particularly prevalent in normative writings.

Carland, Hoy, Boulton and Carland [1] provide a sampling of the definitions appearing in the small business literature. That sampling makes clear that there is no consensus regarding the definition of a small business. Furthermore, the literature does not support the subclassification of small firms. However, most researchers implicitly or explicitly recognize that there are differences among small firms relative to their size. The purpose of a taxonomy is to produce criteria which permit the partitioning of a data set into mutually exclusive categories for more fruitful study and understanding. Such a taxonomy does not exist in the field of small business. 
Numerous state and federal agencies have expressed goals of assisting small businesses. The lack of an established definition and supporting taxonomy impairs their prospects. Nappi and Vori [11] conducted research among government agencies in each of the fifty states and two districts to determine a viable definition of a small business. They found that half the states did not have any definition, while there was no consensus among those definitions which were in use in the remaining states. Furthermore, most agencies could offer no rationale for the definitions or classification criteria which they used. Problems such as these make the need for a taxonomy readily apparent.

\section{Small Business Taxonomy}

The SBA definition does not take into consideration the management structure of a business. Consequently, that definition is of little use in research because both highly complex and simplistic firms can be deemed small through its application. A definition is needed which makes explicit the role of management complexity. Building on the work of McGuire [9], Glueck [6] and Carland, Hoy, Boulton and Carland [1], the following definition is proposed:

A small business is any business which is independently owned and operated, not dominant in its field and consisting of a single strategic business unit.

By this definition, businesses with multiple "profit centers" or "Strategic Business Units" are considered large firms regardless of their sales, employees or other factors. Multiple SBUs create managerial complexity beyond the recognition of needs and demands of a single product/market. The management of such firms must behave differently from managers of small businesses because of this greater complexity in markets and operations.

Chandler's work is of value in understanding the incidence of planning in small business. Structure and strategy are bound. Strategy cannot be seen, but structure can be easily identified. Following Chandler's [2] lead, a taxonomy of small business keyed to their respective management structures is suggested. At the lowest level are firms whose managers personally perform or directly supervise all activities of the organization. Such businesses have no management personnel other than the general manager. These organizations have a single level of management and can therefore be termed "unilevel." Managers of such firms are by necessity operationally oriented.

The second level of the taxonomy includes those businesses which have two levels of management. In other words, there is a level of supervisors between the general manager and the employees. Such firms are "duolevel." There is every reason to believe that the general managers of such firms have some freedom from operational issues as a result of a management layer whose concerns are operational in nature. Hopefully, these managers will use the time freed from operations to practice strategic management or planning. 
The last level of the taxonomy covers those firms which have more than two levels of management. These "multilevel" firms may have more than one member at the general management level. Theoretically speaking, the top managers of these firms can devote themselves to strategic planning because there are management layers whose concerns are operational and tactical.

Regardless of the level of a firm within the taxonomy, it must consist of a single strategic business unit in order to be classified as a small business. This taxonomy has the power to distinguish between groups of small businesses. In other words, the classification criteria make explicit the view that not all small businesses are the same size or complexity. The small business taxonomy described above is illustrated in Figure 1.

Figure 1

Small Business Taxonomy

Multilevel Firms Duolevel Firms Unilevel Firms

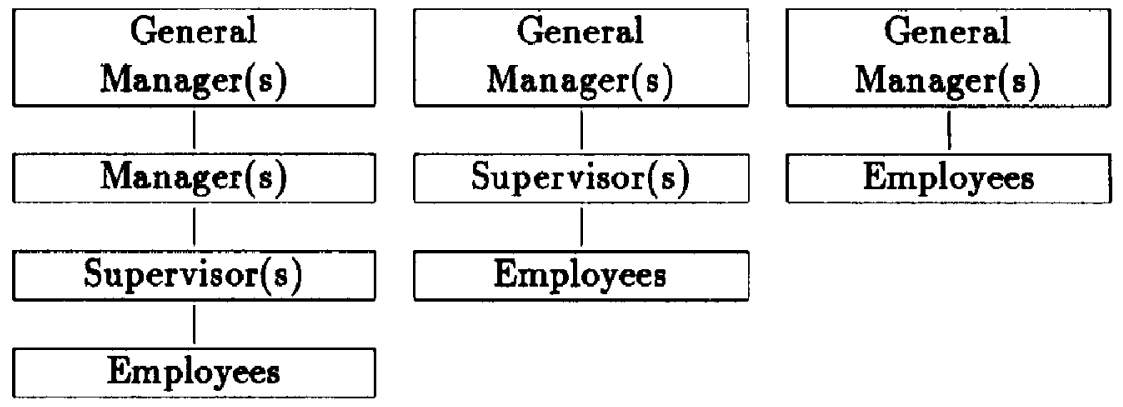

Small businesses may originate at any of the three included levels. After their inception, small businesses may remain stationary, or migrate to different levels of the taxonomy. The creator of the business, the small business practitioner, will define its structure.

\section{Methodology}

Using the theoretical model of a small business taxonomy as the basis for the research, an empirical examination of the incidence of written or unwritten plans was undertaken. Questionnaires were developed which contained inquiries regarding planning, levels of management, and demographic characteristics. In every case the respondent was a small business practitioner.

Each practitioner was asked how many levels of management existed in the business. Respondents were also asked whether there was (1) a formal, written plan for the development and growth of the firm or, (2) an informal, unwritten plan for development and growth. Respondents indicating that neither written nor unwritten plans existed were deemed to have no plans. 


\section{The Sample}

The sample was drawn as part of a class project and included 334 respondents from more than twenty states. Each respondent had started and was currently managing the business. The participants were selected and solicited by graduate students on a convenience basis. Consequently, there was an extremely high ratio of response. Less than one in twenty practitioners approached, declined to participate in the study.

The business owners were active managers and reported that the business consumed the majority of their time and provided most of their family income. All of the businesses would qualify as small firms under the Small Business Administration guidelines for loan assistance. Every firm was independently owned and operated, none were dominant in their fields, and each consisted of a single strategic business unit. Consequently all of the businesses qualify as small firms under our definition as well.

The employee breakdown was as follows: 282 firms reported 10 or fewer employees; 37 reported between 10 and 50 employees; 11 reported 51 to 100 employees; and, 4 reported 101 to 250 employees. In terms of annual sales volume, 169 firms had sales of $\$ 100,000$ or less, 106 had sales between $\$ 100,000$ and $\$ 500,000,29$ had sales between $\$ 500,000$ and $\$ 1,000,000$ and 30 had sales over $\$ 1,000,000$. There were 133 service firms, 15 manufacturing firms, 21 construction companies, 156 retailers and 9 wholesalers. There were 111 corporations, 151 proprietorships and 72 partnerships.

Respondents were asked to indicate the number of levels of management and it was ascertained that 237 firms were unilevel, 66 firms duolevel, and 31 firms were multilevel with regard to the taxonomy. With respect to the existence of plans, 58 firms indicated that formal, written plans existed for the development and growth of the firm; 180 respondents indicated that unwritten plans existed; and, 96 participants indicated that no plans existed for the firm at all. No attempt was made to evaluate appropriateness or effectiveness of plans.

\section{The Research Question}

The research question was whether a relationship existed between the organizational structure of the business and the existence of written or unwritten plans among the sample firms. Theoretically, one would believe that at the unilevel the small business practitioner is too involved with the day-to-day business operations to have the time for developing plans. However, as more management personnel become involved in the operation of the business, one would assume that top management is afforded greater freedom from operational issues and therefore has more time to devote to the development of plans.

\section{Results of the Analysis}

Because the data consists of frequency counts, a Chi Square test is implemented. The Chi Square statistic is designed to measure whether the actual 
frequencies found in a sample differ from the expected frequencies [14]. In this case, the null hypothesis to be tested states that there is no difference in the occurrence of written or unwritten plans between levels in the taxonomy. Consequently, the expected frequencies should be proportionate to the range of possibilities. Our data is divided into three groups: firms with formal, written plans, firms with informal, unwritten plans and firms with no plans. If organizational level makes no difference then all three levels of firms should have the same proportion of respondents in each of the three categories. The number of firms in each category as well as percentages for the breakdown of firms within each level are displayed in Table 1. As shown in the table, the Chi Square test indicated that a significant relationship does exist between the classification of the company within the taxonomy and the existence of written or unwritten plans.

Table 1

Planning vs. Structure

\begin{tabular}{|c|c|c|c|c|c|c|c|c|}
\hline Levels & \multicolumn{2}{|c|}{$\begin{array}{c}\text { Written } \\
\text { Plans }\end{array}$} & \multicolumn{2}{|c|}{$\begin{array}{c}\text { Unwritten } \\
\text { Plans }\end{array}$} & \multicolumn{2}{|c|}{$\begin{array}{c}\text { No } \\
\text { Plans }\end{array}$} & \multicolumn{2}{|c|}{ Totals } \\
\hline Unilevel & 29 & $12.2 \%$ & 129 & $54.4 \%$ & 79 & $33.3 \%$ & 237 & $100.0 \%$ \\
\hline Duolevel & 19 & $28.9 \%$ & 31 & $47.0 \%$ & 16 & $24.2 \%$ & 66 & $100.0 \%$ \\
\hline Multilevel & 10 & $32.3 \%$ & 20 & $64.5 \%$ & 1 & $3.2 \%$ & 31 & $100.0 \%$ \\
\hline Totals & 58 & & 180 & & 96 & & 334 & \\
\hline
\end{tabular}

Further reference to Table 1 reveals that 30 of the 31 multilevel firms had either written or unwritten plans: 10 had written plans and 20 had unwritten plans. At the duolevel, 50 of 66 firms had plans: 19 had written plans and 31 had unwritten plans. Most of the unilevel firms also reported the existence of plans, 79 or $33 \%$ had no plans.

Further investigation was undertaken to determine whether the results of this research were affected by the size of the business. Chi Square tests were conducted between sales volume and the existence of written or unwritten plans and between number of employees and the existence of plans. Both tests indicated that there was no significant difference between firms in the sample classified by sales volume or number of employees and the existence of written or unwritten plans. Consequently, organizational structure appears to be a major factor influencing the occurrence of planning in the sample firms.

\section{Significance of the Findings}

The study demonstrated that differences in the existence of plans existed between sample firms within the proposed taxonomy. We conclude that a case 
exists for a statistically rigorous examination of the taxonomy as a potential classification model for small businesses.

\section{Ramifications for Researchers}

Small business research has been plagued by the absence of a consensual definition. If supported by further research, the definition and taxonomy proposed in this article could provide a tool for greater understanding of small businesses. All small businesses are not alike. The taxonomy could provide researchers with a tool of control for major differences between firms in any data set, thereby increasing the confidence that observed differences in behavior are a result of the factors of interest. The relationship of structure to strategy has long been recognized in large firms; it should be recognized in their smaller counterparts.

\section{Implications for Practitioners}

There has been considerable discussion in the literature about the presence of planning, its value to the business, and its specific content and process (i.e., $[7],[13],[4],[12],[21],[10])$. The impact of planning on long term survival is generally considered positive. In the sample examined in this study, planning was more likely to occur in firms with multiple levels of management. This suggests that practitioners would be well advised to pay more attention to organizational structure if they intend to incorporate planning activities in their firms. If validated by additional research, these findings would imply that organizational issues must be addressed before any issues of quality of planning can be addressed. That is, the ability to plan is in jeopardy without proper organizational structure.

All too often practitioners are wont to shoulder all control and responsibility in their firms. If the findings of this study are valid, a clear need is demonstrated for the delegation of responsibility and authority by any practitioner who wishes to employ strategic planning in the firm. Absent the development of an organizational structure which can nurture planning, it may never exist.

\section{References}

1. Carland, J. W., F. Hoy, W. R. Boulton, and J. A. Carland. "Differentiating Entrepreneurs from Small Business Owners: A Conceptualization." The Academy of Management Review, Vol. 9, No. 2 (April 1984), pp. 354359 .

2. Chandler, A. D., Jr. Strategy and Structure. Cambridge, MA: The Massachusetts Institute of Technology Press (1962).

3. Fredrickson, J. W. and Mitchell, T. R. "Strategic Decision Processes: Comprehensiveness and Performance in an Industry with an Unstable Environment." Academy of Management Journal, Vol. 27 (1984), pp. 399423. 
4. Fry, F. L. and Stoner, C. R. "Business Plans: Two Major Types." Journal of Small Business Management, Vol. 23, No. 1 (January 1985), pp. 1-6.

5. Fulmer, R. M. and Rue, L. W. "The Practice and Profitability of Long Range Planning." Managerial Planning, Vol. 22, No. 6 (1974), pp. 1-7.

6. Glueck, W. F. Business Policy and Strategic Management. New York, NY: McGraw-Hill Book Company (1980).

7. Kelley, C. A. and Young, J. E. "Is Your Small Business Ready for Planning?" Journal of Small Business Management, Vol. 21, No. 1 (January 1983), pp. 28-33.

8. Lindsey, W. M., W. R. Boulton, S. Franklin, and L. W. Rue. "Strategic Planning: Determining the Impact of Environmental Characteristics and Uncertainty." Academy of Management Journal, Vol. 25, No. 3 (1982), pp. 500-509.

9. McGuire, J. W. "The Small Enterprise in Economics and Organization Theory." Journal of Contemporary Business, Vol. 5, No. 2 (1976), pp. 115138.

10. Miller, D. and Toulouse, J. M. "Strategy, Structure CEO Personality and Performance in Small Firms." American Journal of Small Business, Vol. 10, No. 3 (Winter 1986), pp. 47-62.

11. Nappi, A. T. and Vori, J. "Small Business Eligibility: A Definitional Issue." Journal of Small Business Management, Vol. 18, No. 4 (October 1980), pp. 22-27.

12. O'Neill, H. M. and Duker, J. "Survival and Failure in Small Business." Journal of Small Business Management, Vol. 24, No. 1 (January 1986), pp. $30-32$.

13. Orpen, C. "The Effects of Long-Range Planning on Small Business Performance: A Further Examination." Journal of Small Business Management, Vol. 23, No. 1 (January 1985), pp. 16-23.

14. Phillips, J. L. Statistical Thinking. San Francisco, CA: W. H. Freeman and Company (1982).

15. Rhyne, L. C. "The Impact of Strategic Planning on Financial Performance." Paper presented at the 43rd annual meeting of the Academy of Management, Dallas, TX (1983).

16. Rhyne, L. C. "The Relationship of Strategic Planning to Financial Performance." Strategic Management Journal, Vol. 7 (1986), pp. 423-436. 
17. Robinson, R. B. "An Empirical Investigation of the Impact of SBDC Strategic Planning Consultation Upon the Short Term Effectiveness of Small Business in Georgia." Unpublished Doctoral Dissertation, University of Georgia (1980).

18. Robinson, R. B. and Pearce, J. A. "The Impact of Formalized Strategic Planning on Financial Performance in Small Organizations." Strategic Management Journal, Vol. 4, No. 3 (1983), pp. 197-207.

19. Robinson, R. B. "Measures of Small Firm Effectiveness for Strategic Planning Research." Journal of Small Business Management, Vol. 2, No. 2 (April 1983), pp. 22-29.

20. Robinson, R. B., J. A. Pearce, G. S. Vozikis, and T. S. Mescon. "The Relationship Between Stage of Development and Small Firm Planning and Performance." Journal of Small Business Management, Vol. 22, No. 2 (April 1984), pp. 45-52.

21. Robinson, R. B., J. E. Logan, and M. Y. Salem. "Strategic Versus Operational Planning in Small Retail Firms." American Journal of Small Business, Vol. 10, No. 3 (Winter 1986), pp. 7-16.

22. Sanford, M. New Enterprise Management. Reston, VA: Reston Publishing Company (1982).

23. Schollhammer, H. and Kuriloff, A. H. Entrepreneurship and Small Business. New York, NY: John Wiley and Sons (1979).

24. Sexton, D. L. and Van Auken, P. M. "Prevalence of Strategic Planning in Small Business." Journal of Small Business Management, Vol. 20, No. 3 (July 1982), pp. 20-26.

25. Stoner, C. R. "Planning in Small Manufacturing Firms: A Survey." Journal of Small Business Management, Vol. 2, No. 1 (January 1983), pp. 4341.

26. Timmons, J., L. Smallen, and A. Dingee. New Venture Creation: A Guide to Small Business Development. Homewood, IL: Richard D. Irwin (1977).

27. Tootelian, P. H. and Gaedeke, R. M. Small Business Management: Operations and Profiles. Santa Monica, CA: Goodyear (1978).

28. Vozikis, G. and Glueck, W. F. "Small Business Problems and Stages of Development." Academy of Management Proceedings (1980), pp. 373-378. 